\title{
Using non-parametric technical data envelopment analysis - DEA, for measuring productive technical efficiency
}

\author{
Iulian LITA \\ The Bucharest University of Economic Studies, Bucharest, Romania \\ iulian.lita@csie.ase.ro \\ Tănase STAMULE \\ The Bucharest University of Economic Studies, Bucharest, Romania \\ tanase.stamule@fabiz.ase.ro
}

\begin{abstract}
The following study is, in addition to a reassessment of literature and an analysis based on non-parametrical techniques based on linear programming. The analysis based on the Data Envelopment Analisys (DEA) technique will be used to see whether the model that we have used has a significant importance, if there are any substantial differences between the efficiency scores obtained or estimated through various methods. The theoretical part, based on the DEA technique will be analysed under the influence of both the works of Farell(1957), and also Charnes, Cooper, Rhodes(1978), Banker, Charnes, Cooper(1984) and other newer models. The dissolution of efficiency scores obtained through the CRS-DEA model has been studied for a long time into two different components: One is linked with the scale inefficiency and the other one represents the pure technical inefficiency. This dissolution can be done by using the CRS model with technology when not all the companies are operating at the optimum level, i.e. through the simultaneous application on the same set of data of the CRS and VRS models. In this study, the main non-parametrical Data Envelopment Analysis method is presented (Wu, Fan, Zhou, Zhou, 2012; Halkos, Tzeremes, 2009) and its application on a group of 42 companies (The headquarters of a top commercial bank in Romania - S.C. BRD GROUPE SOCIÉTÉ GÉNÉRALE ), based on the information gained in the years 2016-2017. This paper is original because it combines the already developed method with new techniques, in order to link together economic factors and operational research and leaves more room for future researches with the purpose of further assessing and changing the performance of every decisional unit under the influence of the environmental factors.
\end{abstract}

Keywords: efficiency, productivity, technical productive efficiency, non-parametrical techniques, Data Envelopment Analysis, production border, constant and variable return to the scale.

\section{Introduction}

The interest for measuring the efficiency and productivity concerns, on one hand, the success indicators and the performance measures which evaluate the production units (Reinhard, Knox Lovell, Thijssen, 2000; Fried, Lovell, Schmidt, 1993), and on the other hand through measuring the efficiency and productivity (Bampatsou, Papadopoulos, Zervas, 2013), by separating their effects from the effects of the environment, we can highlight the main sources of efficiency, and also highlight the positive variations of productivity (Fallahi, Ebrahimi, Ghaderi, 2011).

The technical productive efficiency (Coelli, Rao, O’Donnell, Battese, 2005) consists of two aspects, namely being either expressed through obtaining increased production rates with the same input quantity, or through using as few production inputs as possible, by obtaining certain production quantities. 
As a result, the productive technical efficiency analysis (Scheel, 2001) may either be oriented towards an increase of the output or have a conservative orientation approach regarding the outputs. The allocative component or price refers to the capacity of combining inputs and outputs in optimal proportions (Nourali, Davoodabadi, Pashazadeh, 2014).

The study of efficiency made by Farrel (1957) has been continued through using general or parametric functions in the definition of the production frontiers (Podinovski, Førsund, 2010; Seiford, Thrall, 1990), however limiting itself to using only one output in the economic analysis. Charnes, Cooper and Rhodes (1978) and others after them have developed linear programming problems applied to the non-parametrical specifications of production possibilities (Wu, Fan, Zhou, Zhou, 2012; Mukherjee, 2008).

Based on Farrells researches (1957), theories that are considered refference points in the study of efficiency have been developed (Alene, Manyong, Gockowski, 2006) such as the deterministic approach of Aigner, Chu (1968), the statistical base of estimating the border of production done by Agrell, Hatami-Marbini (2013), the introduction of the notion of "adjusted method of the least squares”, developed by Egilmez, Kucukvar, Tatari, Bhutta (2014) or the composed error studied by Aigner, Lovell and Schmidt (1977) and independently by Zhou, Ang, Zhou(2012) and also by, Banker, Charnes, Cooper (1984), Cooper, Seiford, Tone (2000).

Based on Dantzig's (1951) and Farrell's (1957) researches, Charnes, Cooper, Rhodes (1978) developed the technique of mathematical programming, introducing the technique of Data Envelopment Analysis-DEA (Charnes, Cooper, Rhodes, 1978), later developed by Song, An, Zhang, Wang, Wu (2012) and Mirhedayatian, Azadi, Saen (2014).

\section{Literature review}

The measurement of a business' performance (Monchuk, Chen, Bonaparte, 2010), is a mandatory focus in order to insure the survival of a business, in the current conditions of a highly dynamic business environment. The following sounding definition of this specific term was given by Neely, Gregory, Platts (1995, p. 107) : "the measurement of performance is the process of action quantification", and a general view of the general business performance measurement is found in Neely's(1999) work.

The necessity of efficiency measurement (Tzouvelekas, Pantzios, Fotopoulos, 2001) has become dominant due to the following reasons: the frequent registered changes in the number and structure of the labor force, the permanent change of the power proportion between the competitors on a particular market (at the level of a particular industry), and the speed of change in information technology, such as the frequent changes in the external competing environment (Wadud, 2003).

Suppose we have inputs and outputs for a batch of K firms, similar in their production activity (Charnes, Cooper, Schinnar, 1977), for which technology is defined through production functions. 


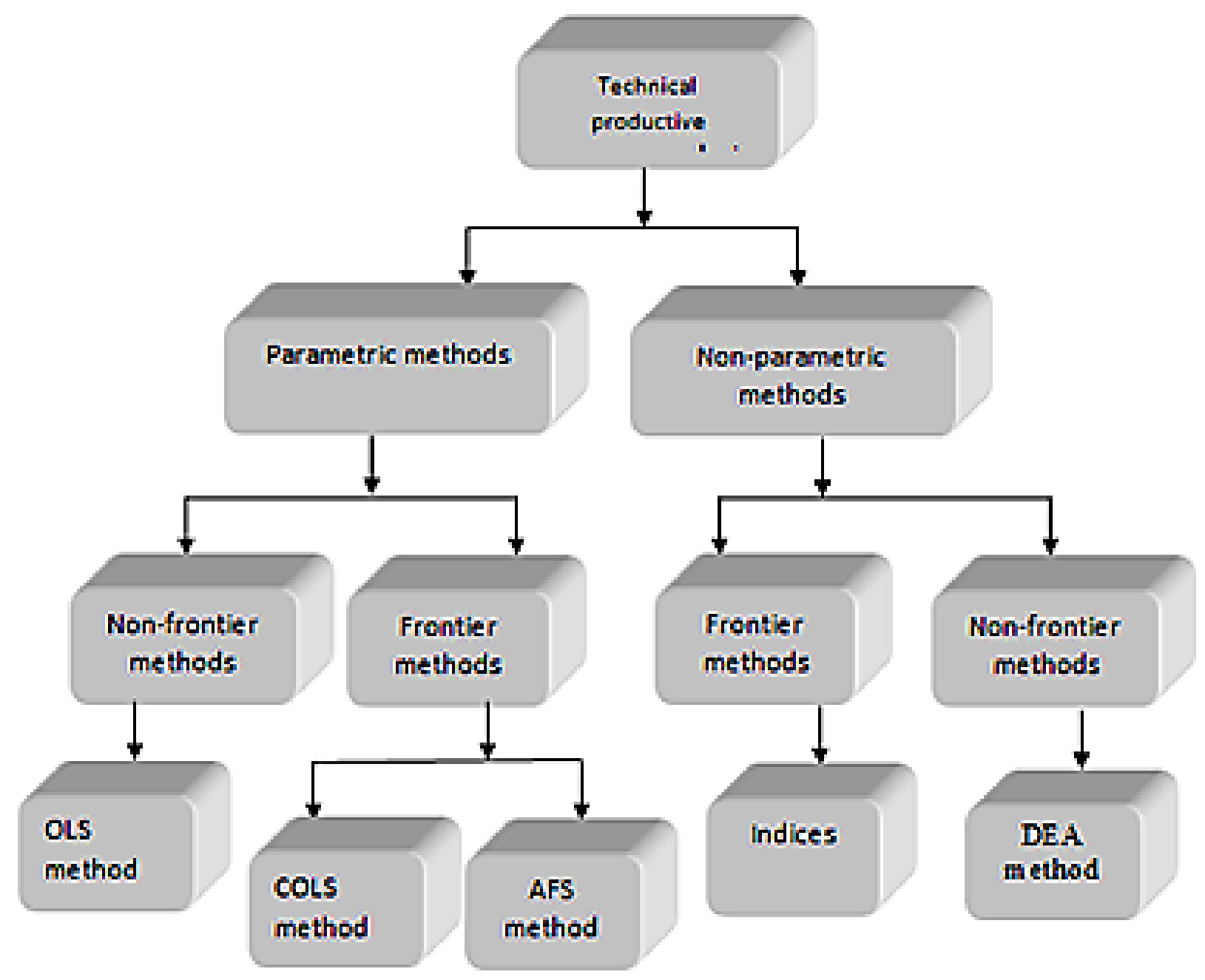

Figure 1. Analysis methods of economic productive efficiency

Source: Author's work according to literature in the field.

The evaluation methods of technical productive efficiency (Sharma, Leung, Zaleski, 1999) can refer not only to intermediate inputs and outputs, but also to the global impact (Asmild, Tam, 2007) at the whole market level, of all specific input factors (Donaldson, 2010, 1987; Robisnon, 1993).

\section{Methodology}

Non-parametric methods of measuring technical productive efficiency (Data Envelopment Analysis DEA)

DEA is a relatively new non-parametric approach (Mukherjee, 2008; Simar, Wilson, 2000) for evaluating the performance of a set of entities, also called decision-making units (DMU) (Charnes, Cooper, Schinnar, 1977; Sun, Wu, Guo, 2013) which convert multiple inputs in 
multiple outputs. The main feature of a decision-making unit (DMU) is that it has control over the production process, converting inputs into outputs.

The conceptual basis of DEA analysis came from Farrell (1957), but was initially limited to evaluating the performance of multiple inputs and only one output -type of decision-making units (DMU).

Thanassoulis (2001) explains the fact that within DEA the resources are typically called inputs and results are named outputs. Inputs and outputs identification within a decision-making unit (DMU) is extremely difficult.

The inputs must include all resources that determine every possible result (Färe, R., Grabowski, R., Grasskopf, S., Kraft, 1997). At the same time, all environmental factors influencing the conversion of inputs in outputs should be mirrored in either inputs and/or outputs, depending on the direction of this impact.

The DEA analysis is therefore a method of measuring relative efficiency, since DEA measurements refer to a set of units which we compare. The efficiency score is usually expressed either as a number between 0 and 1 or as a percentage ranging from 0 to $100 \%$. Every decision-making unit (DMU) that registers a score lower than 1 or $100 \%$ is considered inefficient when compared to other units.

Since the DEA method was firstly introduced in 1978 (Charnes, Cooper, Rhodes, 1978), research in a number of areas showed that DEA is an excellent and easy-to-use methodology for modelling operational processes used in performance evaluation (Yan, Wei, G, 2002).

The DEA models are usually constructed using two specific hypotheses, namely: the constant returns to scale (the original model was proposed by Charnes, Cooper, Rhodes (1978) and is known as the CCR model (Charnes-Cooper-Rhodes)) and the variable returns to scale (the original model was proposed by Banker, Charnes, Cooper (1984) and is known as the BCC model (Banker-Charnes-Cooper)). It is obvious that the variable return to scale is associated with the two possible situations, namely: the increasing and decreasing return to scale respectively.

The DEA method can be thus used to measure firm efficiency, by comparing it with other homogenous units, through converting the same group of measurable positive inputs into the same types of measurable positive outputs.

The fundamental hypothesis, which the efficacy measure using the DEA method is based on, is the homogeneity of both inputs and outputs. Any failure of this hypothesis would obviously affect the relevance of measuring the efficiency across any set of DMU.

The DEA method, which was developed by Charnes, Cooper and Rhodes (1978) and both expanded and developed by Zhu (2017), uses mathematical programming models (Seiford, Thrall, 1990) in order to build the envelopment for crowd of production possibilities $\mathrm{H}$.

An enveloping surface is composed of the hyperplane parts defined in $\mathrm{H}$, as follows:

$$
\sum_{i=1}^{I} \lambda_{i} y_{i}-\sum_{j=1}^{J} \tau_{j} x_{j}+\phi=0
$$

where $\lambda_{1}, \lambda_{2}, \ldots, \lambda_{I},-\tau_{1},-\tau_{2}, \ldots,-\tau_{J}$ and $\phi$ are the hyperplane's coefficients of the hyperplane. 
Such a hyperplane is a supporting- hyperplane (meaning that it forms a facet of the envelopment surface) if and only if all surface points $h^{k}$ are on or under this hyperplane and, additionally, the hyperplane intersects at least one of these points. These conditions can be formulated as follows:

$$
\begin{array}{cc}
\sum_{i=1}^{I} \lambda_{r} y_{i k}-\sum_{j=1}^{J} \tau_{j} x_{j k}+\phi \leq 0 & \text { for } k=1,2, \ldots, K \\
\sum_{i=1}^{I} \lambda_{i} y_{i l}-\sum_{j=1}^{J} \tau_{j} x_{j l}+\phi=0 & \text { for some units } l .
\end{array}
$$

PICBE $\mid 537$

In order to estimate the production frontier, we must then solve $\mathrm{K}$ mathematical programming problems, each decision-making unit being at one point in time an evaluator.

\section{Results and discussions}

The case study involves measuring the productive efficiency of a group of 42 firms (the premises of a leading commercial bank in Romania - S.C. BRD GROUPE SOCIÉTÉ GÉNÉRALE), based on information from 2016-2017.

We will compare the results of these companies with models from both the DEA category and SFA econometric models. For data processing we have used the DEAP2.1 systems for the DEA models and FRONTIER4.1 for the SFA econometric models.

The main objective of the paper is to see whether the model that we have used has a significant importance, if there are any substantial differences between the efficiency scores obtained or estimated through various methods.

We chose two outputs in our analysis: the turnover figure $\left(\mathrm{O}_{1}\right)$ and the net profit $\left(\mathrm{O}_{2}\right)$ and four inputs: total fixed assets $\left(\mathrm{I}_{1}\right)$, total current assets $\left(\mathrm{I}_{2}\right)$, total number of stocks $\left(\mathrm{I}_{3}\right)$, and the average number of employees $\left(\mathrm{I}_{4}\right)$.

\section{CRS-type of DEA models}

The efficiencies for the 2017 activity were calculated in the first instance. These were followed by the Malmquist productivity indices, which were calculated using both 2016 and 2017 data.

The input orientation will be firstly considered. Both envelopment techniques and the DEAP system were used to estimate the efficiency and the production frontier.

In the orientation input describing a technology with constant returns to scale, the 2017 efficiency scores for the group of 42 firms are presented in the following table:

Table 1. Input efficiency CRS scores in 2017

\begin{tabular}{|c|c|c|c|c|c|}
\hline Firm & $\begin{array}{c}\text { Efficiency } \\
\text { in 2017 }\end{array}$ & Firm & $\begin{array}{c}\text { Efficiency } \\
\text { in 2017 }\end{array}$ & Firma & $\begin{array}{c}\text { Efficiency } \\
\text { in 2017 }\end{array}$ \\
\hline 1 & 0.854 & 15 & $\mathbf{1 . 0 0 0}$ & 29 & 0.518 \\
\hline 2 & $\mathbf{1 . 0 0 0}$ & 16 & 0.621 & 30 & 0.285 \\
\hline 3 & 0.889 & 17 & 0.492 & 31 & 0.113 \\
\hline 4 & 0.634 & 18 & 0.857 & 32 & $\mathbf{1 . 0 0 0}$ \\
\hline 5 & 0.795 & 19 & 0.493 & 33 & 0.584 \\
\hline
\end{tabular}




\begin{tabular}{|c|c|c|c|c|c|}
\hline 6 & 0.732 & 20 & 0.153 & 34 & 0.322 \\
\hline 7 & 0.368 & 21 & 0.274 & 35 & $\mathbf{1 . 0 0 0}$ \\
\hline 8 & $\mathbf{1 . 0 0 0}$ & 22 & 0.634 & 36 & 0.496 \\
\hline 9 & 0.779 & 23 & 0.578 & 37 & 0.189 \\
\hline 10 & $\mathbf{1 . 0 0 0}$ & 24 & 0.421 & 38 & $\mathbf{1 . 0 0 0}$ \\
\hline 11 & 0.586 & 25 & $\mathbf{1 . 0 0 0}$ & 39 & 0.083 \\
\hline 12 & 0.682 & 26 & $\mathbf{1 . 0 0 0}$ & 40 & 0.094 \\
\hline 13 & $\mathbf{1 . 0 0 0}$ & 27 & 0.618 & 41 & 0.623 \\
\hline 14 & 0.314 & 28 & 0.497 & 42 & 0.491 \\
\hline \multicolumn{7}{|c|}{ AVERAGE } \\
\hline
\end{tabular}

PICBE | 538

Companies 2, 8, 10, 13, 15, 25, 26, 32, 35 and 38 were found to be effective in 2017 . Interpretation of result of the score for Company 3, for example, is as follows: The company should reduce proportionally all its inputs $11,1 \%$ without reducing its output and then it becomes effective (the firm's score being 0,889). We have the same interpretation for the others companies. It is noted that the most inefficient firms in the input are 20, 31, 37, 39 and 40 , with a score below 0.2 .

For the year 2016, only the decision-making units that had the highest and lowest The average of the efficiency scores obtained for 2017 is 0,594.

Efficiency scores and those that were the best and the least good in 2017 are presented. Keeping all 42 companies in the analysis were found to be effective firms: 2, 5, 8, $10,25,26,32,35,38$, and the lowest efficiency score was obtained by company 40 and not by 39 as in 2017 . Firms 20 and 31 have a very low efficiency score in 2016 too. The results are presented in Table 2:

Table 2. Input efficiency CRS scores in the years 2016 and 2017

\begin{tabular}{|c|c|c|c|}
\hline Firm & $\begin{array}{c}\text { Efficiency } \\
\text { in } 2016\end{array}$ & $\begin{array}{c}\text { Efficiency } \\
\text { in } 2017\end{array}$ & Comments \\
\hline 2 & 1.000 & 1.000 & Efficiency in both years \\
\hline 5 & 1.000 & 0.795 & Efficiency in 2016, relatively good score in 2017 \\
\hline 8 & 1.000 & 1.000 & Efficiency in both years \\
\hline 10 & 1.000 & 1.000 & Efficiency in both years \\
\hline 25 & 1.000 & 1.000 & Efficiency in both years \\
\hline 26 & 1.000 & 1.000 & Efficiency in both years \\
\hline 16 & 1.000 & 0.621 & Efficiency in 2016, relatively small score in 2017 \\
\hline 32 & 1.000 & 1.000 & Efficiency in both years \\
\hline 35 & 1.000 & 1.000 & Efficiency in both years \\
\hline 38 & 1.000 & 1.000 & Efficiency in both years \\
\hline 40 & 0.119 & 0.094 & Very low efficiency score in both 2016 and 2017 \\
\hline 39 & 0.129 & 0.083 & The lowest efficiency score in 2016 and 2017 \\
\hline 13 & 0.835 & 1.000 & Relatively high score in 2016, efficiency in 2017 \\
\hline 14 & 0.563 & 0.314 & Relatively small score in 2016, even worse in 2017 \\
\hline 20 & 0.147 & 0.153 & Very low efficiency score in both 2016 and 2017 \\
\hline 31 & 0.122 & 0.113 & Very low efficiency score in both 2016 and 2017 \\
\hline
\end{tabular}

Source: Authors' work. 
It is noticeable that firms $2,8,10,25,26,32,35,38$ have remained effective. Generally, there were no spectacular increases or decreases in the efficiency scores of other firms, with average efficiency scores in 2016 being 0,638, slightly higher than in 2017.

VRS-type of DEA models

PICBE $\mid 539$

DEA VRS model, input oriented

Constant scale returns CRS is a suitable condition when all decision-making units operate on the same scale (optimal). Imperfect competition, financial restrictions, etc. can cause situations when the company cannot act on the optimum scale.

In this situation we are talking about variable returns to scale: increasing (irs) or decreasing (drs). Thus, the following efficiency scores for 2017 were obtained in the input orientation describing a technology with variable returns to scale:

Table 3. CRS and VRS efficiency input scores in 2017

\begin{tabular}{|c|c|c|c|c|c|c|c|c|c|c|c|c|c|c|}
\hline \multirow{2}{*}{$\begin{array}{c}\text { Fir } \\
\text { m }\end{array}$} & \multicolumn{4}{|c|}{$\begin{array}{c}\text { Efficiency in 2017, } \\
\text { in case of }\end{array}$} & \multirow[t]{2}{*}{$\begin{array}{c}\text { Fir } \\
\mathbf{m}\end{array}$} & \multicolumn{4}{|c|}{$\begin{array}{l}\text { Efficiency in 2017, } \\
\text { in case of }\end{array}$} & \multirow[t]{2}{*}{$\begin{array}{c}\text { Fir } \\
\text { m }\end{array}$} & \multicolumn{4}{|c|}{$\begin{array}{c}\text { Efficiency in 2017, } \\
\text { in case of }\end{array}$} \\
\hline & CRS & VRS & $\begin{array}{c}\text { Scal } \\
\text { e }\end{array}$ & $\begin{array}{c}\text { Typ } \\
\text { e }\end{array}$ & & CRS & VRS & $\begin{array}{c}\text { Scal } \\
\text { e }\end{array}$ & $\begin{array}{c}\text { Typ } \\
\text { e }\end{array}$ & & CRS & VRS & Scale & $\begin{array}{c}\text { Typ } \\
\text { e }\end{array}$ \\
\hline 1 & 0.854 & 0.892 & $\begin{array}{r}0.95 \\
7 \\
\end{array}$ & irs & 15 & $\begin{array}{c}1.00 \\
0\end{array}$ & $\begin{array}{c}1.00 \\
0 \\
\end{array}$ & 1 & - & 29 & 0.518 & $\begin{array}{c}1.00 \\
0\end{array}$ & 0.518 & irs \\
\hline 2 & $\begin{array}{c}1.00 \\
0\end{array}$ & $\begin{array}{c}1.00 \\
0\end{array}$ & 1 & - & 16 & 0.621 & 0.682 & $\begin{array}{r}0.91 \\
0\end{array}$ & irs & 30 & 0.285 & 0.324 & 0.879 & drs \\
\hline 3 & 0.889 & $\begin{array}{c}1.00 \\
0\end{array}$ & $\begin{array}{r}0.88 \\
9 \\
\end{array}$ & irs & 17 & 0.492 & 0.521 & $\begin{array}{r}0.94 \\
4 \\
\end{array}$ & $\mathrm{drs}$ & 31 & 0.113 & 0.189 & 0.597 & irs \\
\hline 4 & 0.634 & 0.695 & $\begin{array}{r}0.91 \\
2 \\
\end{array}$ & - & 18 & 0.857 & $\begin{array}{c}1.00 \\
0\end{array}$ & $\begin{array}{r}0.85 \\
7\end{array}$ & drs & 32 & $\begin{array}{c}1.00 \\
0\end{array}$ & $\begin{array}{c}1.00 \\
0\end{array}$ & 1 & - \\
\hline 5 & 0.795 & 0.814 & $\begin{array}{r}0.97 \\
6\end{array}$ & - & 19 & 0.493 & 0.515 & $\begin{array}{r}0.95 \\
7\end{array}$ & irs & 33 & 0.584 & $\begin{array}{c}1.00 \\
0\end{array}$ & 0.584 & $\mathrm{drs}$ \\
\hline 6 & 0.732 & 0.782 & $\begin{array}{r}0.93 \\
6 \\
\end{array}$ & drs & 20 & 0.153 & 0.184 & $\begin{array}{r}0.83 \\
1 \\
\end{array}$ & $\mathrm{drs}$ & 34 & 0.322 & 0.367 & 0.877 & drs \\
\hline 7 & 0.368 & 0.391 & $\begin{array}{r}0.94 \\
1 \\
\end{array}$ & $\mathrm{drs}$ & 21 & 0.274 & 0.291 & $\begin{array}{r}0.94 \\
1 \\
\end{array}$ & $\mathrm{drs}$ & 35 & $\begin{array}{c}1.00 \\
0\end{array}$ & $\begin{array}{c}1.00 \\
0\end{array}$ & 1 & $\mathrm{drs}$ \\
\hline 8 & $\begin{array}{c}1.00 \\
0\end{array}$ & $\begin{array}{c}1.00 \\
0\end{array}$ & 1 & - & 22 & 0.634 & $\begin{array}{c}1.00 \\
0\end{array}$ & $\begin{array}{r}0.63 \\
4 \\
\end{array}$ & - & 36 & 0.496 & 0.534 & 0.928 & drs \\
\hline 9 & 0.779 & $\begin{array}{c}1.00 \\
0\end{array}$ & $\begin{array}{r}0.77 \\
9 \\
\end{array}$ & irs & 23 & $\begin{array}{l}0.578 \\
\end{array}$ & 0.594 & $\begin{array}{r}0.97 \\
3 \\
\end{array}$ & irs & 37 & 0.189 & 0.217 & 0.870 & irs \\
\hline 10 & $\begin{array}{c}1.00 \\
0\end{array}$ & $\begin{array}{c}1.00 \\
0\end{array}$ & 1 & - & 24 & 0.421 & 0.471 & $\begin{array}{r}0.89 \\
3\end{array}$ & irs & 38 & $\begin{array}{c}1.00 \\
0\end{array}$ & $\begin{array}{c}1.00 \\
0\end{array}$ & 1 & - \\
\hline 11 & 0.586 & 0.623 & $\begin{array}{r}0.94 \\
0 \\
\end{array}$ & drs & 25 & $\begin{array}{c}1.00 \\
0\end{array}$ & $\begin{array}{c}1.00 \\
0\end{array}$ & 1 & - & 39 & 0.083 & 0.092 & 0.902 & drs \\
\hline 12 & 0.682 & 0.711 & $\begin{array}{r}0.95 \\
9 \\
\end{array}$ & $\mathrm{drs}$ & 26 & $\begin{array}{c}1.00 \\
0\end{array}$ & $\begin{array}{c}1.00 \\
0\end{array}$ & 1 & - & 40 & 0.094 & 0.112 & 0.839 & $\mathrm{drs}$ \\
\hline 13 & $\begin{array}{c}1.00 \\
0\end{array}$ & $\begin{array}{c}1.00 \\
0\end{array}$ & 1 & - & 27 & 0.618 & 0.663 & $\begin{array}{r}0.93 \\
2 \\
\end{array}$ & $\mathrm{drs}$ & 41 & 0.623 & 0.673 & 0.925 & - \\
\hline 14 & 0.314 & 0.354 & $\begin{array}{r}0.88 \\
7 \\
\end{array}$ & irs & 28 & 0.497 & $\begin{array}{c}1.00 \\
0\end{array}$ & $\begin{array}{r}0.49 \\
7 \\
\end{array}$ & irs & 42 & 0.491 & 0.543 & 0.904 & irs \\
\hline & & & & & ERA & & & & & & $\begin{array}{r}0.59 \\
4\end{array}$ & $\begin{array}{r}0.68 \\
5\end{array}$ & $\begin{array}{r}0.86 \\
7\end{array}$ & - \\
\hline
\end{tabular}

Source: Authors' work.

DOI: 10.2478/picbe-2018-0048, pp. 533-543, ISSN 2558-9652| Proceedings of the $12^{\text {th }}$ International Conference on Business Excellence 2018 
In the first column are presented the efficiency scores relative to a CRS frontier, in the second column are presented the efficiency scores related to a VRS frontier and in the "Scale" column, their ratio. It is also presented the type of returns to scale, namely: irs for increasing returns, respectively drs for decreasing returns.

These firms appear to be effective inputs after VRS technology: 2, 3, 8, 9, 10, 13, 15, $18,22,25,26,28,29,32,33,35,38$, which have the efficiency score equal to 1 . The other companies can be classified in order decreasing by the efficiency score values. An analysis of the returns type leads us to the conclusion that only 13 companies in the analyzed lot have increasing returns to scale, 16 of them having decreasing returns to scale and the remaining 13 constant returns.

Scale efficiency is calculated as the ratio between the two CRS and VRS results:

$$
\mathrm{SE}=\frac{T E_{C R S}}{T E_{V R S}}
$$

For the total of 42 companies, the following average results were obtained: $\mathrm{TE}_{\mathrm{CRS}}=$ $0,594, \mathrm{TEVRS}_{\mathrm{V}}=0,685$ şi $\mathrm{SE}=0,867$, indicating an envelopment quite close to that given by CRS technology. The average of 2017 efficiency scores for VRS is higher than that obtained for CRS.

The DEA VRS model, outputs oriented

The following table shown the results obtained from the 2017 analysis of the companies:

Table 4. Efficiency scores in VRS in both guidelines in 2017

\begin{tabular}{|c|c|c|c|c|c|c|c|c|}
\hline \multirow[t]{2}{*}{ Firm } & \multicolumn{2}{|c|}{$\begin{array}{l}\text { VRS Efficiency, } \\
\text { oriented }\end{array}$} & \multirow[t]{2}{*}{ Firm } & \multicolumn{2}{|c|}{$\begin{array}{l}\text { VRS Efficiency, } \\
\text { oriented }\end{array}$} & \multirow[t]{2}{*}{ Firm } & \multicolumn{2}{|c|}{$\begin{array}{l}\text { VRS Efficiency, } \\
\text { oriented }\end{array}$} \\
\hline & inputs & outputs & & inputs & outputs & & inputs & outputs \\
\hline 1 & 0.892 & 0.912 & 15 & 1.000 & 1.000 & 29 & 1.000 & 1.000 \\
\hline 2 & 1.000 & 1.000 & 16 & 0.682 & 0.621 & 30 & 0.324 & 0.475 \\
\hline 3 & 1.000 & 1.000 & 17 & 0.521 & 0.543 & 31 & 0.189 & 0.345 \\
\hline 4 & 0.695 & 0.725 & 18 & 1.000 & 1.000 & 32 & 1.000 & 1.000 \\
\hline 5 & 0.814 & 0.882 & 19 & 0.515 & 0.678 & 33 & 1.000 & 1.000 \\
\hline 6 & 0.782 & 0.791 & 20 & 0.184 & 0.298 & 34 & 0.367 & 0.421 \\
\hline 7 & 0.391 & 0.420 & 21 & 0.291 & 0.439 & 35 & 1.000 & 1.000 \\
\hline 8 & 1.000 & 1.000 & 22 & 1.000 & 1.000 & 36 & 0.534 & 0.643 \\
\hline 9 & 1.000 & 1.000 & 23 & 0.594 & 0.672 & 37 & 0.217 & 0.324 \\
\hline 10 & 1.000 & 1.000 & 24 & 0.471 & 0.654 & 38 & 1.000 & 1.000 \\
\hline 11 & 0.623 & 0.689 & 25 & 1.000 & 1.000 & 39 & 0.092 & 0.111 \\
\hline 12 & 0.711 & 0.823 & 26 & 1.000 & 1.000 & 40 & 0.112 & 0.134 \\
\hline 13 & 1.000 & 1.000 & 27 & 0.663 & 0.820 & 41 & 0.673 & 0.782 \\
\hline 14 & 0.354 & 0.393 & 28 & 1.000 & 1.000 & 42 & 0.543 & 0.652 \\
\hline & & & VERAC & & & & 0.685 & 0.793 \\
\hline
\end{tabular}

Source: Authors' own work. 
An analysis of the type of returns to the scale in the output orientation leads us to the conclusion that even one of the companies in the analyzed lot does not have increasing returns to the scale.

For the total of 42 companies, the following average results were obtained $T E_{C R S}=$ $0,685, T E_{V R S}=0,793$ and $S E=0,864$, indicating an envelopment not very close to that given by VRS technology.

\section{Conclusions}

It should be noted that the fact that in the assumption of constant returns to scale, the scores are the same for the DEA model with output orientation.

Generally, the two CRS and VRS frontiers are very close, with scale efficiency above 0.9 for most of the companies; only company 28 and 29 has a scale efficiency below 0.5 . Therefore, we can say that firms have an activity close to the optimal technological scale. To become effective, company 8 will have to reduce proportionally all inputs by about $90 \%$.

In the case of output orientation, reference firms (those located on the estimated frontier) are: $2,3,8,9,10,13,15,18,22,25,26,28,29,32,33,35,38$. It is noticeable that all firms are on the estimated frontier.

It is easy to see that in the case of the output-oriented DEA-VRS model, the same firms as the targeted input model were found to be effective. However, it is no longer a rule that the scores obtained are higher or lower than those obtained in the case DEA-VRSoriented inputs. By comparing the scores in the two cases, we note that they have close values, which was to be expected.

\section{References}

Aigner, D. J., Chu, S.F. (1968), On estimating the industry production function. American Economic Review, 58, 226-239.

Agrell, P.J., Hatami-Marbini, A. (2013), Frontier-based performance analysis models for supply chain management: State of the art and research directions, Computers \& Industrial Engineering, 66, 567-583.

Alene, A. D., Manyong, V.M., Gockowski, J. (2006), The production efficiency of intercropping annual and perennial crops in southern Ethiopia: A comparison of distance functions and production frontiers, Agricultural Systems, 91, 51-70.

Asmild, M., Tam, F. (2007), Estimating global frontier shifts and global Malmquist indices, Journal of Productivity Analysis, 27, 137-148.

Bampatsou, C., Papadopoulos, S., Zervas, E. (2013), Technical efficiency of economic systems of EU-15 countries based on energy consumption, Energy Policy, 55(4), 426-434

Banker, R. D., Charnes, A., Cooper, W.W.(1984), Some models for estimating technical and scale inefficiencies in data envelopment analysis, ManagementScience, 30, 10781092.

Charnes, A., Cooper, W.W., Rhodes, E. (1978), Measuring efficiency of decision making units, European Journal of Operational Research, 3(2), 429-444. 
Charnes, A., Cooper, W.W., Schinnar, A.. (1977), Transforms and approximations in cost and production function relations, Research Report CCS 284, Austin, TX, University of Texas Center for Cybernetic Studies.

Coelli, T.J., Rao, D.S.P., O’Donnell, C.J., Battese, G.E. (2005), An introduction to efficiency and productivity analysis, Springer science and business media, New York.

Cooper, W.W., Seiford, L.M., Tone, K. (2000), Data Envelopment Analysis, Kluwer Academic Publishers, Boston.

Dantzig, G. B., (1951), Maximization of a linear function of variables subject to linear inequalities, In T. C. Koopmans (Ed.), Activity analysis of production and allocation, New York: Wiley.

Donaldson, C. (2010), The state of the art of costing health care for economic evaluation, Community Health Stud, 14, 341-356. http://dx.doi.org/10.1111/j.1753-6405.1990.tb00045.x

Egilmez, G., Kucukvar, M., Tatari, O., Bhutta, M.K.S. (2014), Supply chain sustainability assessment of the U.S. food manufacturing sectors: A life cycle-based frontier approach, Resources, Conservation and Recycling,. 82(1),8-20.

Farrell, M. J. (1957), The measurement of productive efficiency, Journal of the Royal Statistical Society, Series A, 120 (III), 253-281.

Färe, R., Grabowski, R., Grasskopf, S., Kraft, S. (1997), Efficiency of a fixed but allocable input: A non-parametric approach, Economics Letters, 56, 187-193.

Fried, H.O., Lovell, C.A.K., Schmidt, S.S. (1993), The Measurement of Productive Efficiency: Techniques and Applications, Oxford University Press.

Halkos, G. E., Tzeremes, N. G. (2009), Exploring the existence of Kuznets curve in countries' environmental efficiency using. DEA window analysis, Ecological Economics, 68, 2168-2176.

Huang, R., Li, Y., (2013), Undesirable input-output two-phase DEA model in an environmental performance audit, Mathematical and Computer Modelling, 58(9), 971-979.

Mirhedayatian, S.M., Azadi, M., Saen, R.F., (2014), A novel network data envelopment analysis model for evaluating green supply chain management, International Journal of Production Economics, 147, 544-554.

Monchuk, D.C., Chen, Z., Bonaparte, Y. (2010), Explaining production inefficiency in China's agriculture using data envelopment analysis and semi-parametric bootstrapping, China Economic Review, 21, 346-354.

Mukherjee, K. (2008), Energy use efficiency in U.S. manufacturing: A nonparametric analysis, Energy Economics, 30(1), 76-96.

Neely, A., Gregory, M., Platts, K. (1995), Performance Measurement System Design, A literature review and research agenda, International Journal of Operation \& Production Management, 15 (1995) 80-116. http://dx.doi.org/10.1108/0144357951008 3622

Neely, A. (1999), The Performance Measurement revolution: why now and what next, International Journal of Operation \& Production Management, MCB University Press, 19 (2) 205-228. http://dx.doi.org/10.1108/01443579910247437 
Nourali, A. E., Davoodabadi, M., Pashazadeh, H. (2014), Regulation and Efficiency \& Productivity Considerations in Water\&Wastewater Industry: Case of Iran, Procedia Social and Behavioral Sciences, 109(1), 281-289.

Reinhard, S., Knox Lovell, C.A., Thijssen, G.J. (2000), Environmental efficiency with multiple environmentally detrimental variables; estimated with SFA and DEA, European Journal of Operational Research, 121, 287-303.

PICBE $\mid 543$

Robisnon, R. (1993), Economic analysis and health care, What does it mean?, Br Med J., 307, 670-673, http://dx.doi.org/10.1136/bmj.307.6905.670

Scheel, H. (2001), Undesirable outputs in efficiency valuations, European Journal Of Operational Research 132, 400-410.

Sharma, K.R., Leung, P., Zaleski, H.M. (1999), Technical, allocative and economic efficiencies in swine production in Hawaii: a comparison of parametric and nonparametric approaches, Agricultural Economics, 20, 23-35.

Simar, L., Wilson, P.W. (2000), Statistical inference in nonparametric frontier models: the state of the art, Journal of Productivity Analysis, 13, 49-78.

Song, M., An, Q., Zhang, W.,Wang, Z., Wu, J. (2012), Environmental efficiency evaluation based on data envelopment analysis: A review. Renewable and Sustainable Energy Reviews, 16, 4465-4469.

Sun, J., Wu, J., Guo, D. (2013), Performance ranking of units considering ideal and antiideal DMU with common weights, Applied Mathematical Modelling, 37(5/1), 6301-6310.

Tzouvelekas, V, Pantzios J., Fotopoulos C. (2001), Technical efficiency of alternative farming systems: the case of Greek organic and conventional olive-growing farms, Food Policy 26, 549-569.

Wu, F., Fan, L. W., Zhou, P.,Zhou, D. Q. (2012), Industrial energy efficiency with CO2 emissions in China: A nonparametric analysis, Energy Policy, 49, 164-172.

Yan, H., Wei, Q., G., H. (2002), DEA models for resource reallocation and production input/output estimation, European Journal of Operation Research, 136(1), 1931.

Zhou, P., Ang, B.W., Zhou, D.Q. (2012), Measuring economy-wide energy efficiency performance: A parametric frontier approach, Applied Energy, 90(2), 196-200.

Zhu, Z., Wang, K., Zhang, B. (2014), Applying a network data envelopment analysis model to quantify the eco-efficiency of products: a case study of pesticides, Journal of Cleaner Production, 69, 67-73. 